\title{
Targeting the glycans of the HIV envelope as a therapeutic tool
}

\author{
Jan Balzarini \\ From Frontiers of Retrovirology 2011 \\ Amsterdam, The Netherlands. 3-5 October 2011
}

Carbohydrate-binding agents (CBA) represent a broad family of agents that recognize specific glycan conformations. Several members of this compound family including peptidicprokaryotic, plant, invertebrate and vertebrate lectins, but also the well-defined non-peptidicpradimicin and benanomicin antibiotics have shown to be endowed with anti-HIV activity. These compounds inhibit entry of virus particles in susceptible T-lymphocytes and macrophages, block syncytia formation between HIV-infected and non-infected T-lymphocytes, prevent capture of HIV by DC-SIGN-expressing cells and by the macrophage mannose receptor and prevent subsequent transmission of captured HIV to susceptible T-lymphocytes. No other antiviral class of compounds have been demonstrated to block these four important ways of HIV infection/transmission, which make the CBAs an interesting new family of potential anti-HIV drugs that may be particularly useful for both systemic and topical (i.e. microbicidal) applications. CBAs bind to the glycans of the HIV envelope gpl 20 and block viral entry, most likely by freezing the envelope conformation during viral entry. Escalating drug pressure in HIVinfected cell cultures result in the selection of mutant virus strains predominantly having one or several $\mathrm{N}$-glycan deletions in their envelope gp120.ln this respect, many CBAs have a high genetic barrier since several Nglycan deletions seem to be required for significant phenotypic drug resistance. Interestingly, mutant virus strains containing an increasing amount of $\mathrm{N}$-glycan deletions in gp120 tend to show a compromised ínfectivity potential. Moreover, we have found one specific, highly conserved N-glycan in HIV-1 gp120, whose deletion results in the production of noninfectious virus particles lacking gp41gp120 in their envelope. This Nglycan may be regarded as a hot-spot for a targeted

Rega Institute for Medical Research, K.U.Leuven, B-3000 Leuven, Belgium therapeutic intervention. Also, it is expected that if mutant virus particles lacking $\mathrm{N}$-glycans in gp120 are selected under CBA pressure in vivo, as shown to occur in drug-exposed HIV-and SIV-infected cell cultures, previously hidden conserved immunogenic epitopes become exposed, allowing the immune system to specifically trigger an efficient immune response against these viruses. An in vivo study using SIV-infected monkeys has been planned to explore this new therapeutic concept.

Published: 3 October 2011

doi:10.1186/1742-4690-8-S2-O38

Cite this article as: Balzarini: Targeting the glycans of the HIV envelope as a therapeutic tool. Retrovirology 2011 8(Suppl 2):O38.

Submit your next manuscript to BioMed Central and take full advantage of:

- Convenient online submission

- Thorough peer review

- No space constraints or color figure charges

- Immediate publication on acceptance

- Inclusion in PubMed, CAS, Scopus and Google Scholar

- Research which is freely available for redistribution

Submit your manuscript at www.biomedcentral.com/submit
() Biomed Central 